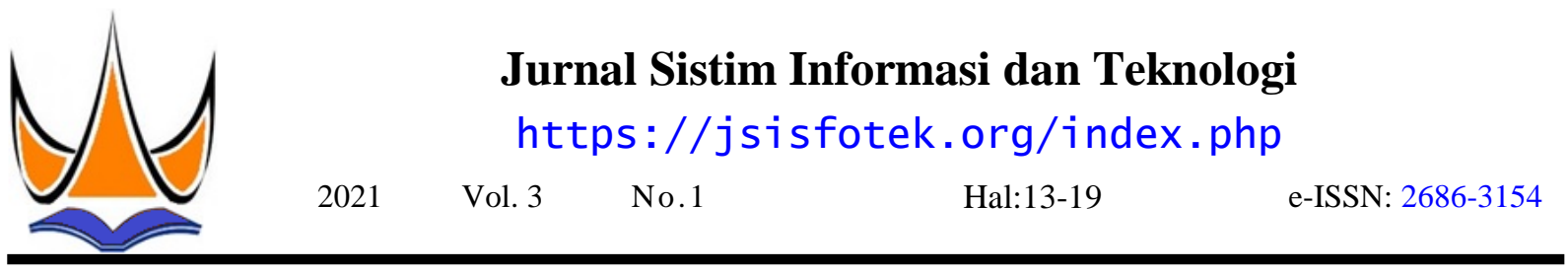

\title{
Sistem Pakar Menggunakan Metode Case Based Reasoning dalam Akurasi Penyakit Disebabkan oleh Bakteri Staphylococcus Aureus
}

\author{
Surya Aulia Rahman ${ }^{1 凶}$ Sumijan $^{2}$ \\ Universitas Putra Indonesia YPTK Padang \\ suryaau1ia01@gmai1.com
}

\begin{abstract}
Staphylococcus aureus is the most worrisome bacteria in the world of health because it is highly pathogenic and can cause serious infections in previously healthy individuals. Staphylococcus aureus has gram-positive cells, round (cocci) 0.7-0.9 $\mu \mathrm{m}$ in diameter, non-spore-forming, non-motile, facultative anoerobes, in colony shaped like a grape string. This bacterial infection in humans varies in severity, from minor skin infections (furunculosis and impertigo), urinary tract infections, respiratory infections, to eye infections. This causes many patients to need an expert (doctor) to consult about the symptoms that a patient appears or experiences and the risk factors felt by the patient. So they conducted this research using the Case Based Reasoning (CBR) method which consists of 4 steps, namely retrieve, reuse, retain and revise. By using the case-based reasoning method for a problem with the staphylococcus aureus bacterial disease, it is easier for a patient to find treatment and a solution. With an expert system using this method (case based reasoning), experts (doctors) can easily find out what diseases are suffered by staphylococcus. That way, patients with staphylococcus disease are prepared to deal with the disease they are suffering from.
\end{abstract}

Keywords: Expert System, Staphylococcus Aureus, Case Based Reasoning, PHP, Database MySQL.

\begin{abstract}
Abstrak
Staphylococcus Aureus adalah merupakan bakteri yang paling mencemaskan di dunia kesehatan karena sangat patogen dan dapat menyebabkan infeksi berat pada individu yang tadinya sehat. Staphylococcus aureus memiliki sel yang bersifat gram positif, berbentuk bulat (kokus) berdiameter 0,7-0,9 $\mu \mathrm{m}$, tidak membentuk spora, tidak motil, anoerob fakultatif, dalam koloni berbentuk khas seperti rangkaian anggur. Infeksi bakteri ini pada manusia memiliki tingkat keparahan yang bervariasi, mulai infeksi minor pada kulit (furunkulosis dan impertigo), infeksi saluran kemih, infeksi saluran pernafasan, sampai infeksi pada mata. Hal ini menyebabkan banyaknya pasien yang membutuhkan pakar (dokter) untuk berkonsultasi mengenai gejalagejala yang muncul atau dialami seorang pasien dan faktor resiko yang dirasakan oleh pasien. Maka mereka melakukan penelitian ini dengan menggunakan metode Case Based Reasoning (CBR) yang terdiri dari 4 langkah yaitu retrieve, reuse, retain dan revise. Dengan menggunakan metode case based reasoning untuk suatu masalah penyakit bakteri staphylococcus aureus, maka seorang pasien lebih mudah mendapati penanganan dan solusinya. Dengan adanya sistem pakar menggunakan metode (case based reasoning) ini, maka pakar (dokter) bisa dengan mudah mengetahui penyakit yang diderita pada staphylococcus. Dengan begitu pasien penyakit staphylococcus mempersiapkan diri untuk mengatasi penyakit yang dideritanya.
\end{abstract}

Kata kunci: Sistem Pakar, Staphylococcus Aureus, Case Based Reasoning, Php, Database MySQL.

(C) 2021 JSisfotek

\section{Pendahuluan}

Sistem Pakar adalah sistem aplikasi berbasis komputer yang digunakan untuk menyelesaikan masalah sebagaimana yang dipikirkan oleh pakar. Pakar yang dimaksud di sini adalah orang yang mempunyai keahlian khusus yang dapat menyelesaikan masalah yang tidak dapat diselesaikan oleh orang awam [1]. Cara kerja dari sistem pakar ini yaitu dengan meniru Kecerdasan Buatan berasal dari bahasa Inggris proses pengetahuan dan pemikiran seorang pakar dalam "Artificial Intelligence" atau disingkat AI, yaitu menyelesaikan suatu masalah lalu pengetahuan tersebut Kecerdasan Buatan adalah salah satu bagian ilmu dimasukkan ke dalam sebuah sistem komputer agar komputer yang membuat agar mesin (komputer) dapat masalah tersebut dapat diselesaikan dengan mudah.

Staphylococcus Aureus adalah merupakan bakteri yang paling mencemaskan di dunia kesehatan karena sangat patogen dan dapat menyebabkan infeksi berat pada individu yang tadinya sehat [2]. Hal ini menyebabkan banyaknya pasien yang membutuhkan pakar (dokter) untuk berkonsultasi mengenai gejala-gejala yang muncul atau dialami seorang pasien dan faktor resiko yang dirasakan oleh pasien. Maka mereka melakukan penelitian ini dengan menggunakan metode Case Based Reasoning (CBR) yang terdiri dari 4 langkah yaitu retrieve, reuse, retain dan revise.

melakukan pekerjaan seperti dan sebaiknya yang dilakukan oleh manusia [3]. Kecerdasan Buatan dapat didefenisikan merupakan konsep yang memiliki spesialisasi dalam penghimpunan pengetahuan yang dapat diterapkan ke dalam sistem. Dalam dijelaskan

Diterima: 07-10-2020 | Revisi: 21-10-2020 | Diterbitkan: 31-03-2021 | DOI: 10.37034/jsisfotek.v3i1.38 
bahwa kecerdasan buatan didefenisikan sebagai ilmu Banyak penelitian menggunakan CBR dalam AI [6], yang berkaitan dengan teknologi komputer yang di [7], [8], maka penelitian ini membangun sistem pakar dalamnya telah dimasukkan pengetahuan dan informasi dalam melakukan perhitungan menggunakan metode [4].

Case Based Reasoning (CBR) merupakan salah satu metode yang menggunakan kecerdasan buatan atau Artificial Intelligence (AI) yang brusaha mengadopsi pengetahuan manusia ke komputer, agar komputer dapat menyelesaikan masalah seperti yang bisa dilakukan oleh para ahli. CBR adalah salah satu metode untuk membangun sistem dengan pengambilan keputusan untuk memecahkan kasus atau masalah yang baru dengan cara mengingat solusi darikasus lama atau sebelumnya dengan menggunakan informasi dan pengetahuan pada situasi tersebut. CBR dapat digunakan untuk menyimpan dan menggunakan kembali pengetahuan dari pengalaman sebelumnya [5].

Salah satu cabang dari (Artificial Intellegence) AI yang dapat diartikan sebagai sebuah perangkat komputer yang memiliki basis pengetahuan untuk bidang tertentu yang menggunakan inferensi yang menyerupai seorang pakar dalam memecahkan masalah. Dengan adanya sistem pakar menggunakan metode (case based reasoning) ini, maka pakar (dokter) bisa dengan mudah mengetahui penyakit yang diderita pada staphylococcus Data gejala yang didapatkan dari sumber data yang aureus. Dengan begitu pasien penyakit staphylococcus telah dikonsultasikan dengan pakar disajikan pada aureus mempersiapkan diri untuk mengatasi penyakit Tabel 1sampai dengan Tabel 8. yang dideritanya.

\section{Metodologi Penelitian}

Penelitian ini merupakan system pakar dalam akurasi penyakit disebabkan oleh bakteri Staphylococcus Aureus. Penelitian dirinci dalam tahapan dalam bentuk alur dengan urutan langkah-langkahnya disajikan pada Tabell.

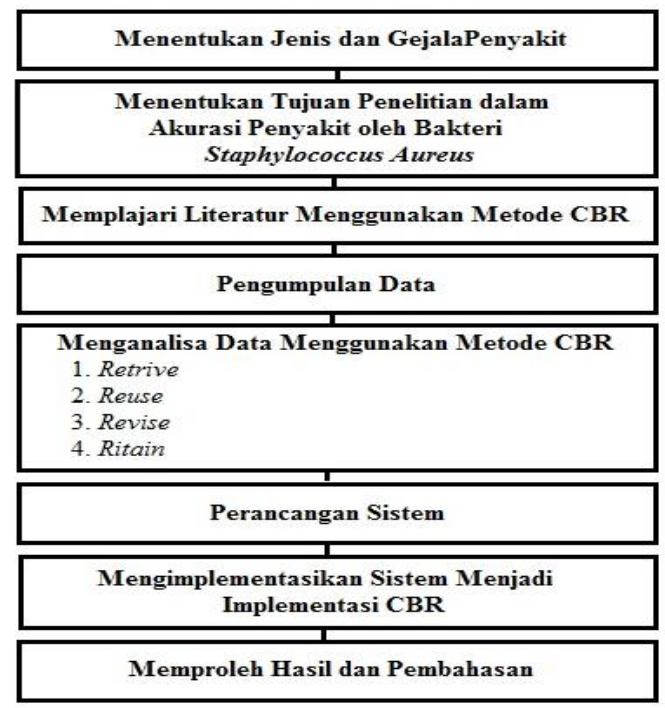

Gambar 1. Kerangka Kerja Penelitian
CBR. Data yang diolah oleh metode ini merupakan data-data penyakit berupa informasi tentang jenis, gejala dan solusi terhadap penyakit bakteri staphylococcus aureus pada manusia. Data penyakit tersebut diperoleh dari hasil wawancara dengan dokter spesialis penyakit bakteri staphylococcus aureus.

\section{Hasil dan Pembahasan}

Objek yang diolah pada penelitian ini adalah data gejala-gejala yang terdapat pada beberapa jenis penyakit disebabkan oleh bakteri staphylococcus aureus. Penjelasan mengenai gejala-gejala terhadap jenis penyakit disebabkan oleh bakteri staphylococcus aureusdikelompokan menjadi tiga, yaitu:

a. Pengelompokkan gejala ringan dengan bobot parameter (w): 1

b. Pengelompokkan gejala sedang dengan bobot parameter $(\mathrm{w}): 3$

c. Pengelompokkan gejala berat dengan bobot parameter (w): 5

Tabel 1. Gejala Penyakit Folikulitis

\begin{tabular}{|c|c|c|c|}
\hline $\begin{array}{l}\mathrm{N} \\
\mathrm{o}\end{array}$ & $\begin{array}{l}\text { Nama } \\
\text { Penyakit }\end{array}$ & Gejala Awal & Bobot \\
\hline 1. & Folikulitis & $\begin{array}{ll}\text { 1. } & \text { Infeksi pada folikel rambut } \\
\text { 2. } & \text { Bintik berwarna merah } \\
\text { 3. } & \text { Bintik berisi nanah } \\
\text { 4. } & \text { Bintik berisi nanah yang } \\
& \text { banyak } \\
\text { 5. Terasa hangat saat diraba } \\
\text { 6. Terasa gatal } \\
\text { 7. Terasa nyeri } \\
\text { 8. Terjadi pada kulit kepala } \\
\text { 9. Terjadi pada lipatan ketiak } \\
\text { 10. Terjadi pada bokong } \\
\text { 11. } & \text { Terjadi pada paha } \\
\end{array}$ & $\begin{array}{l}5 \\
1 \\
3 \\
5 \\
\\
3 \\
1 \\
5 \\
3 \\
3 \\
3 \\
3 \\
\end{array}$ \\
\hline \multicolumn{4}{|c|}{ Tabel 2. Gejala Penyakit Furunkel/Karbunkel(Bisul) } \\
\hline $\begin{array}{l}\mathrm{N} \\
\mathrm{o}\end{array}$ & $\begin{array}{l}\text { Nama } \\
\text { Penyakit }\end{array}$ & Gejala Awal & Bobot \\
\hline 2 & $\begin{array}{l}\text { Furunkel/ } \\
\text { karbunkel } \\
\text { (Bisul) }\end{array}$ & $\begin{array}{l}\text { 1. Pada awalnya muncul bintik } \\
\text { merah yang keras kemudian } \\
\text { membesar } \\
\text { 2. Bintik merah berisi nanah } \\
\text { menjadi bisul } \\
\text { 3. Terasa gatal } \\
\text { 4. Terasa nyeri } \\
\text { 5. Kulit disekitar bisul terlihat } \\
\text { merah, bengkak } \\
\text { 6. Terasa hangat ketika disentuh } \\
\text { 7. Bisul memiliki titik putih di } \\
\text { bagian puncak } \\
\text { 8. Bisul pecah mengeluarkan nanah } \\
\text { 9. Bisul hanya satu di jumpai } \\
\text { 10. Bisul jumlahnya banyak } \\
\text { 11. Badan terasa hangat dan demam } \\
\text { 12. Terjadi pada lipatan ketiak } \\
\text { 13. Terjadi pada bokong }\end{array}$ & $\begin{array}{l}3 \\
1 \\
5 \\
5\end{array}$ \\
\hline
\end{tabular}

Jurnal Sistim Informasi dan Teknologi Vol. 3 No. 1 (2021) 13-19 
Surya Aulia Rahman, Sumijan.

Tabel 3. Gejala Penyakit Impetigo Bulosa

\begin{tabular}{|c|c|c|c|}
\hline No & $\begin{array}{l}\text { Nama } \\
\text { Penyakit }\end{array}$ & Gejala Awal & Bobot \\
\hline \multirow{12}{*}{3.} & \multirow{12}{*}{$\begin{array}{l}\text { Impetigo } \\
\text { Bulosa }\end{array}$} & 1. Muncul bintik merah & 1 \\
\hline & & $\begin{array}{l}\text { 2. Muncul gelembung berisi } \\
\text { cairan }\end{array}$ & 3 \\
\hline & & $\begin{array}{l}\text { 3. Muncul gelembung berisi } \\
\text { nanah yang banyak }\end{array}$ & 5 \\
\hline & & 4. Terasa gatal & 1 \\
\hline & & 5. Terasa nyeri & 5 \\
\hline & & $\begin{array}{l}\text { 6. Gelembung tersebut mudah } \\
\text { pecah, menyebar, dan } \\
\text { menimbulkan keropeng }\end{array}$ & 5 \\
\hline & & $\begin{array}{l}\text { berwarna kuning seperti } \\
\text { madu }\end{array}$ & \\
\hline & & $\begin{array}{l}\text { 7. Badan terasa hangat dan } \\
\text { demam }\end{array}$ & 5 \\
\hline & & 8. Terjadi pada lipatan ketiak & 3 \\
\hline & & 9. Terjadi pada wajah & 5 \\
\hline & & 10. Terjadi pada punggung & 3 \\
\hline & & 11. Terjadi pada dada & 3 \\
\hline
\end{tabular}

Tabel 4. Gejala Penyakit Paronikia

\begin{tabular}{|c|c|c|c|}
\hline No & $\begin{array}{l}\text { Nama } \\
\text { Penyakit }\end{array}$ & Gejala Awal & Bobot \\
\hline \multirow{9}{*}{4.} & \multirow{9}{*}{ Paronikia } & $\begin{array}{l}\text { 1. Kemerahan / peradangan } \\
\text { pada kulit kuku di sekitar } \\
\text { kuku }\end{array}$ & 3 \\
\hline & & $\begin{array}{l}\text { 2. Biasanya didahului oleh } \\
\text { trauma (garukan) }\end{array}$ & 1 \\
\hline & & $\begin{array}{l}\text { 3. Awalnya berupa infeksi pada } \\
\text { lipatan kuku }\end{array}$ & 1 \\
\hline & & 4. Infeksi mengenai kuku & 3 \\
\hline & & $\begin{array}{l}\text { 5. Infeksi mengenai jaringan } \\
\text { dibawah kuku }\end{array}$ & 5 \\
\hline & & $\begin{array}{l}\text { 6. Tumpukan nanah dibawah } \\
\text { kuku }\end{array}$ & 5 \\
\hline & & 7. Terasa gatal & 1 \\
\hline & & 8. Terasa nyeri & 5 \\
\hline & & $\begin{array}{l}\text { 9. Terjadi pada jari tangan atau } \\
\text { kaki }\end{array}$ & 5 \\
\hline \multicolumn{4}{|c|}{ Tabel 5. Gejala Penyakit Selulitis } \\
\hline No & $\begin{array}{l}\text { Nama } \\
\text { Penyakit }\end{array}$ & Gejala Awal & Bobot \\
\hline \multirow{6}{*}{5.} & \multirow{6}{*}{ Selulitis } & $\begin{array}{l}\text { 1. Peradangan pada kulit dan } \\
\text { jaringan sekitar disertai } \\
\text { adanya pelunakan jaringan } \\
\text { dibawah kulit }\end{array}$ & 5 \\
\hline & & $\begin{array}{l}\text { 2. Badan terasa hangat dan } \\
\text { demam }\end{array}$ & 5 \\
\hline & & $\begin{array}{l}\text { 3. Biasanya didahului oleh } \\
\text { trauma seperti garukan }\end{array}$ & 1 \\
\hline & & $\begin{array}{l}\text { 4. Jika tidak diobati akan } \\
\text { semakin melebar dan } \\
\text { perlunakan semakin banyak }\end{array}$ & 5 \\
\hline & & 5. Terasa gatal & 1 \\
\hline & & 6. Terasa nyeri & 5 \\
\hline
\end{tabular}

Tabel 6. Gejala Penyakit Flegmon

\begin{tabular}{|c|c|c|c|}
\hline No & $\begin{array}{l}\text { Nama } \\
\text { Penyakit }\end{array}$ & Gejala Awal & Bobot \\
\hline \multirow{4}{*}{6.} & \multirow{4}{*}{ Flegmon } & $\begin{array}{l}\text { 1. Peradangan pada kulit dan } \\
\text { jaringan sekitar disertai adanya } \\
\text { perlunakan jaringan dibawah } \\
\text { kulit dan timbunan cairan nanah } \\
\text { dibawah kulit (supurasi) }\end{array}$ & 5 \\
\hline & & 2. Badan terasa hangat dan demam & 5 \\
\hline & & $\begin{array}{l}\text { 3. Biasanya didahului oleh trauma } \\
\text { seperti garukan }\end{array}$ & 1 \\
\hline & & 4. Terasa nyeri & 5 \\
\hline
\end{tabular}

Tabel 7. Gejala Penyakit Ulkus/tukak

\begin{tabular}{|c|c|c|c|}
\hline No & $\begin{array}{l}\text { Nama } \\
\text { Penyakit }\end{array}$ & Gejala Awal & Bobot \\
\hline \multirow{6}{*}{7.} & \multirow{6}{*}{$\begin{array}{l}\text { Ulkus } \\
\text { Tukak }\end{array}$} & $\begin{array}{l}\text { 1. Timbulnya tukak pada kulit } \\
\text { disertai nanah didalamnya dan } \\
\text { peradangan daerah disekitar kulit }\end{array}$ & 5 \\
\hline & & $\begin{array}{l}\text { 2. Tukak berukuran kecil dan } \\
\text { dangkal }\end{array}$ & 1 \\
\hline & & 3. Tukak berukuran besar & 3 \\
\hline & & $\begin{array}{l}\text { 4. Tukak berukuran besar dan } \\
\text { dalam }\end{array}$ & 5 \\
\hline & & $\begin{array}{ll}\text { 5. } & \text { Terasa gatal } \\
\text { 6. } & \text { Terasa nyeri }\end{array}$ & $\begin{array}{l}1 \\
5\end{array}$ \\
\hline & & 7. Terjadi pada tungkai bawah & 3 \\
\hline
\end{tabular}

Tabel 8. Gejala Penyakit Impetigo Krustosa

\begin{tabular}{|c|c|c|c|}
\hline No & $\begin{array}{l}\text { Nama } \\
\text { Penyakit }\end{array}$ & Gejala Awal & Bobot \\
\hline \multirow{8}{*}{8.} & \multirow{8}{*}{$\begin{array}{l}\text { Impetigo } \\
\text { Krustosa }\end{array}$} & 1. $\quad$ Bercak merah & 1 \\
\hline & & 2. Bintik merah & 1 \\
\hline & & $\begin{array}{l}\text { 3. Gelembung yang mudah pecah } \\
\text { dan kropeng tebal berwarna } \\
\text { kuning seperti madu melebar } \\
\text { kedaerah sekitar }\end{array}$ & 5 \\
\hline & & 4. Terasa gatal & 1 \\
\hline & & 5. Adanya batuk dan pilek & 5 \\
\hline & & 6. Mengenai wajah & 5 \\
\hline & & 7. Mengenai hidung & 5 \\
\hline & & 8. Mengenai mulut & 5 \\
\hline
\end{tabular}

Selanjutnya, dilakukan proses analisis terhadap gejala ringan dengan nilai 1 , gejala sedang dengan nilai 3 dan gejala berat dengan nilai 5 menggunakan metode CBR.

Sistem ini menggunakan langkah yang digunakan dalam metode CBR. Dalam metode CBR terdapat 4 tahap proses, yaitu proses retrieve, reuse, revise dan ritain. Sistem ini umumnya berpedoman kepada basis pengetahuan yang dimiliki oleh sistem itu sendiri. Basis pengetahuan bersumber dari kasus-kasus yang pernah didiagnosa sebelumnya oleh seorang pakar spesialis penyakit disebabkan oleh bakteri staphylococcus aureus kemudian dihitung tingkat kemiripannya dimana dengan cara memasukkan kasus baru yang dialamioleh pengguna. Berdasar tingkat kemiripan inilah sistem akan mendiagnosa jenis penyakit pada bakteri stapylococcus aureus. Persamaan yang digunakan disajikan pada Rumus (1). 
Similarity $($ problem, case $)=\frac{s 1 * w 1+s 2 * w 2+\cdots+s n * w n}{w 1+w 2+\cdots+w n}$

Dimana s1, s2, dan seterusnya adalah jumlah gejala penyakit sedangakan $\mathrm{w}$ adalah bobot penyakit yang disajikan pada Tabel 1 sampai dengan Tabel 8 . Pengujian terhadap penyakit yangdisebabkan oleh bakteri Staphylococcus Aureusdengan menggunakan Rumus (1) disajikan pada Tabel 9.

Tabel 9. Data Pengujian

\begin{tabular}{lll}
\hline Kode & Gejala yang dipilih user & Bobot \\
\hline S13 & Bintik merah berisi nanah menjadi bisul & 3 \\
S07 & $\begin{array}{l}\text { Terasa nyeri } \\
\text { Kulit disekitar bisul terlihat merah, }\end{array}$ & 5 \\
& 5 & \\
S14 & bengkak & 3 \\
S05 & Terasa hangat saat diraba & 5 \\
S16 & Bisul pecah mengeluarkan nanah & 5 \\
S18 & Bisul jumlahnya banyak & 5 \\
S19 & Badan terasa hangat dan demam & 3 \\
S11 & Terjadi pada paha & 5 \\
\hline
\end{tabular}

Maka tingkat kemiripannya yang berhubungan dengan gejala penyakit Folikulitis adalah:

$$
\begin{aligned}
& \text { Similarity (problem, case) } \\
& =\frac{s 1 * w 1+s 2 * w 2+\cdots+s n * w n}{w 1+w 2+\cdots+w n}
\end{aligned}
$$$$
(1 * 5)+(1 * 1)+(1 * 3)+(0 * 5)+(0 * 3)+(1 * 1)+(0 * 5)+
$$$$
=\frac{(0 * 3)+(0 * 3)+(0 * 3)+(0 * 3)}{5+1+3+5+3+1+5+3+3+3+3}
$$$$
=\frac{10}{35}=0,28
$$$$
=28 \%
$$

Dari perhitungan kasus diatas terdapat 4 gejala yang dialami oleh user yang memiliki kemiripan dengan kasus lama, sehingga dari perhitungan similarity, tingkat penyakit folikulitis yang dialami oleh user sebesar $28 \%$.

Untukperhitungan kemiripan berdasarkan. gejalapenyakit Furunkel/Karbunkel(Bisul) adalah :

$$
\begin{aligned}
& \text { Similarity (problem, case) }=\frac{s 1 * w 1+s 2 * w 2+\cdots+s n * w n}{w 1+w 2+\cdots+w n} \\
& =\frac{(0 * 1)+(1 * 3)+(0 * 1)+(1 * 5)+(1 * 5)+(1 * 3)+(0 * 3)+(1 * 5)+}{(0 * 1)+(1 * 5)+(1 * 5)+(0 * 3)+(0 * 3)} \\
& 1+3+1+5+5+3+3+5+1+5+5+3+3
\end{aligned}
$$$$
=\frac{31}{43}=0,72
$$$$
=72 \%
$$

Dari perhitungan kasus diatas terdapat 7 gejala yang dialami oleh user yang memiliki kemiripan dengan kasus lama, sehingga dari perhitungan similarity, tingkat penyakit furunkel/karbunkelang (busul) yang dialami oleh user sebesar $72 \%$.
Untuk perhitungan kemiripan berdasarkan. gejalapenyakitImpetigo Bulosa adalah :

$$
\begin{aligned}
& \text { Similarity (problem, case })=\frac{s 1 * w 1+s 2 * w 2+\cdots+s n * w n}{w 1+w 2+\cdots+w n} \\
& =\frac{(0 * 1)+(0 * 3)+(1 * 5)+(0 * 1)+(1 * 5)+(1 * 5)+(1 * 5)+(1 * 3)}{+(0 * 5)+(1 * 3)+(1 * 3)} \\
& =\frac{29}{39}=0,74
\end{aligned}
$$

$=74 \%$

Dari perhitungan kasus diatas terdapat 7 gejala yang dialami oleh user yang memiliki kemiripan dengan kasus lama, sehingga dari perhitungan similarity, tingkat penyakit impetigo bulosa yang dialami oleh user sebesar $74 \%$.

Untuk perhitungan kemiripan berdasarkan. gejalapenyakit Selulitis adalah :

Similarity $($ problem, case $)=\frac{s 1 * w 1+s 2 * w 2+\cdots+s n * w n}{w 1+w 2+\cdots+w n}$

$=\frac{(1 * 5)+(0 * 5)+(1 * 1)+(0 * 5)+(0 * 1)+(1 * 5)}{5+5+1+5+1+5}$

$=\frac{11}{22}=0,5$

$=50 \%$

Dari perhitungan kasus diatas terdapat 3 gejala yang dialami oleh user yang memiliki kemiripan dengan kasus lama, sehingga dari perhitungan similarity, tingkat penyakit selulitis yang dialami oleh user sebesar $50 \%$.

Untuk perhitungan kemiripan berdasarkan.

gejalapenyakitParonikia adalah :

Similarity $($ problem, case $)=\frac{s 1 * w 1+s 2 * w 2+\cdots+s n * w n}{w 1+w 2+\cdots+w n}$

$=\frac{(1 * 3)+(1 * 1)+(1 * 1)+(0 * 3)+(0 * 5)+(0 * 5)+(1 * 1)+(1 * 5)+(1 * 5)}{3+1+1+3+5+5+1+5+5}$

$=\frac{16}{29}=0,55$

$=55 \%$

Dari perhitungan kasus diatas terdapat 6 gejala yang dialami oleh user yang memiliki kemiripan dengan kasus lama, sehingga dari perhitungan similarity, tingkat penyakit paronikia yang dialami oleh user sebesar $55 \%$.

Untuk perhitungan kemiripan berdasarkan. gejalapenyakitFlegmon adalah :

Similarity $($ problem, case $)=\frac{s 1 * w 1+s 2 * w 2+\cdots+s n * w n}{w 1+w 2+\cdots+w n}$ 
$=\frac{(1 * 5)+(0 * 5)+(1 * 1)+(0 * 5)}{5+5+1+5}$

$=\frac{6}{16}=0,37$

$=37 \%$

Dari perhitungan kasus diatas terdapat 2 gejala yang dialami oleh user yang memiliki kemiripan dengan kasus lama, sehingga dari perhitungan similarity, tingkat penyakit flegmon yang dialami oleh user sebesar $37 \%$.

Untuk perhitungan kemiripan berdasarkan. gejala penyakitUlkus/tukak adalah :

Similarity (problem, case $)=\frac{s 1 * w 1+s 2 * w 2+\cdots+s n * w n}{w 1+w 2+\cdots+w n}$

$=\frac{(0 * 5)+(1 * 1)+(0 * 3)+(1 * 5)+(0 * 1)+(1 * 5)+(1 * 3)}{5+1+3+5+1+5+3}$

$=\frac{14}{23}=0,61$

$=61 \%$

Dari perhitungan kasus diatas terdapat 4 gejala yang dialami oleh user yang memiliki kemiripan dengan kasus lama, sehingga dari perhitungan similarity, tingkat penyakit ulkus/tukak yang dialami oleh user sebesar $61 \%$.

Untuk perhitungan kemiripan berdasarkan. gejala penyakitImpetigo Krustosa adalah :

Similarity $($ problem, case $)=\frac{s 1 * w 1+s 2 * w 2+\cdots+s n * w n}{w 1+w 2+\cdots+w n}$

$=\frac{(0 * 1)+(1 * 1)+(1 * 5)+(0 * 1)+(0 * 5)+(0 * 5)+(1 * 5)+(1 * 5)}{1+1+5+1+5+5+5+5}$

$=\frac{16}{28}=0,57$

$=57 \%$

Dari perhitungan kasus diatas terdapat 4 gejala yang dialami oleh user yang memiliki kemiripan dengan kasus lama, sehingga dari perhitungan similarity, tingkat penyakit impetigo krustosa dialami oleh user sebesar $57 \%$.

Dari perhitungan kasus diatas, kasus yang memiliki bobot kemiripan paling rendah yaitu kasus pada jenis penyakit Folikulitis dengan nilai $28 \%$ dan kasus yang diimputkan ada 4 gejala dengan kemiripan pada basis pengetahuan. Untuk kasus yang memiliki bobot kemiripan yang tertinggi yaitu kasus pada jenis Impetigo Bulosa dengan nilai $74 \%$ dimana terdapat 7 gejala yang diimputkan memiliki kesamaan dengan gejala pada basis pengetahuan.

Pada proses reuse, solusi yang diberikan adalah solusi dengan bobot kemiripan kasus yang paling tinggi nilai similarity-nya yaitu penyakit Impitigo Krustosa.Jadi solusinya adalah.

a. Menjaga kebersihan kulit dengan mandi 2x sehari.

b. Hindari berbagi handuk, alatcukur atau pakaian pada oranglain

c. Membiasakan cuci tangan secara teratur dengan sabun

d. Hindari garukan pada kulit

e. Rutin berolahraga dan makan makanan sehat untuk menjaga ketahanan tubuh

Penelitian ini juga didukung dengan pembangunan system yang diaplikasikan dengan menggunakan pemrograman PHP dan database MySQL. Inilah bentuk tampilan halaman depan pada sistem pakar menggunakan metode case based reasoning dalam akurasi penyakit disebabkan oleh bakteri stpahylococcus aureus pada Gambar 2.

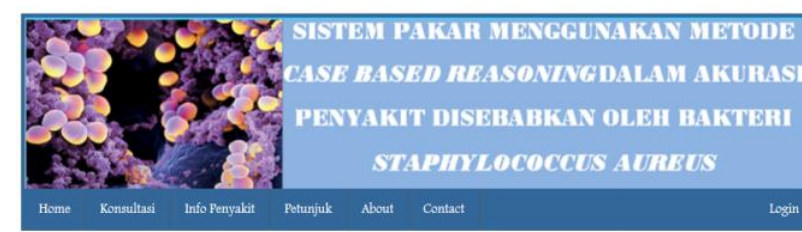

SELAMAT DATANG DI SISTEM PAKAR DALAM AKURASI PENYAKTT DISEBABKAN OLEH BAKTERI STAPHYLOCOCCUS AUREUS

Penyalit kulit merupakan kondisi saat lapisan luar tubuh mengalami masalah baik initasi ataut meradane, Kondiss ini hise vebabkan kulit gatal bersisik, perih. hingga memerah. Penvakit kulit termasulk masslah yang sangat umum teriadi Massleh kuli bisa menyerang siapa pun dari berbagai rentang usia. Bayi. anak orang dewasa hingga orang traa bisa terkena masalah kesechatan yang

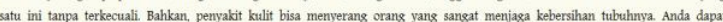

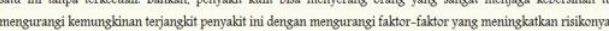

Staphylococeus aereus adalah salah satu jenis hakteri Staphylocececus Jika dilihat di bawah mikrsskop, hakteri Staphylococcus an tampak seperti sekelompok angegur. Terdanat lebih dari 30 jenis bakteri staphylococcuss, namun bakteri Staphylococceus auners dalah tipe yang paling sering menyebabkan penyakit

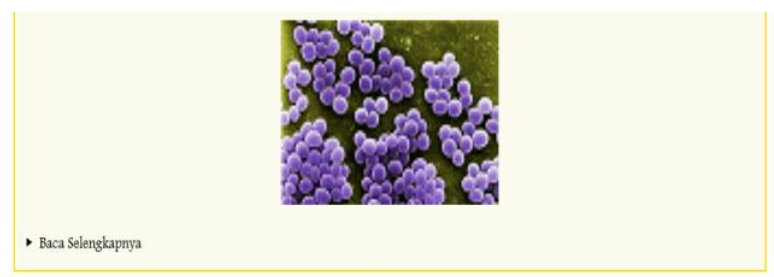

SISTEM PARAR FENYART DISBABRAN OLFH BARTER STAPHYLOCOCCUS AURRUS

Gambar 2. Halaman Depan

Tampilan halaman konsultasi pasien pada Gambar 3. 

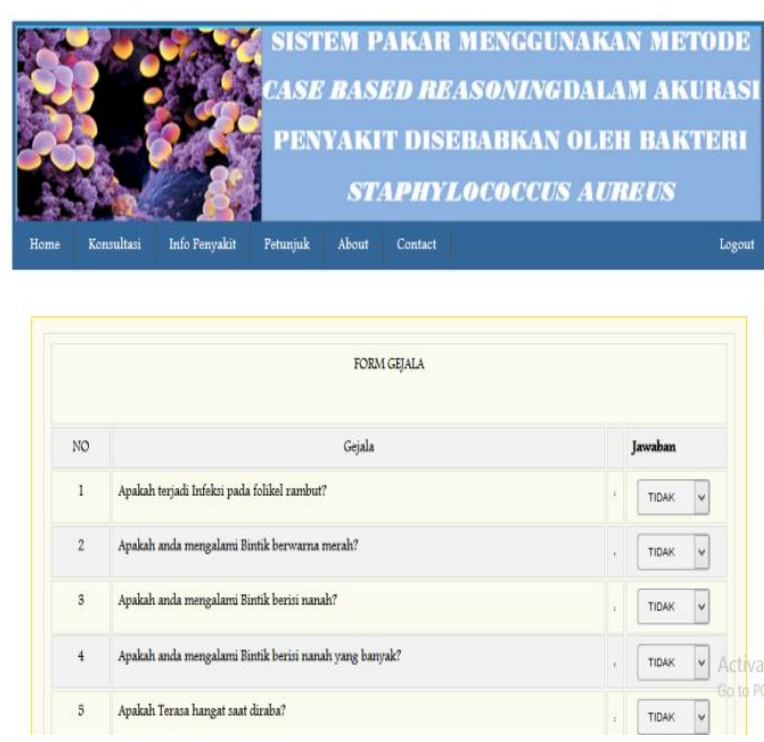

Gambar 3. Halaman Konsultasi

Setelah gejala diisi berdasarkan yang dirasakan oleh user, maka diproses menggunakan metode CBR dan menghasilkan tampilan seperti pada Gambar 4 (a) dan (b).

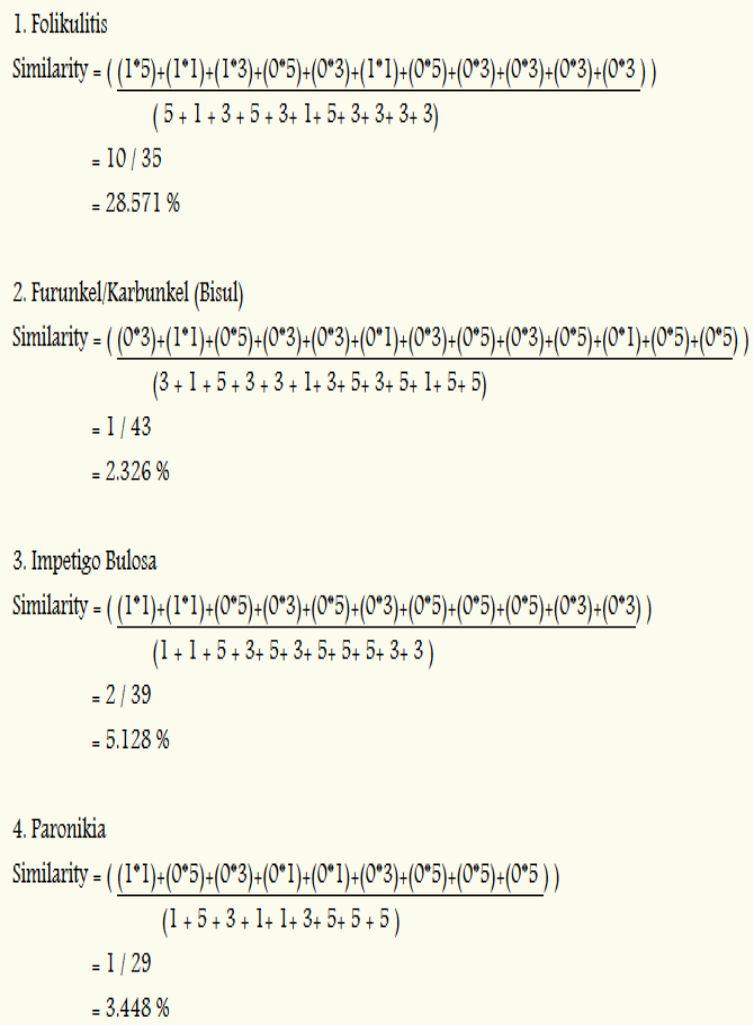

(a)

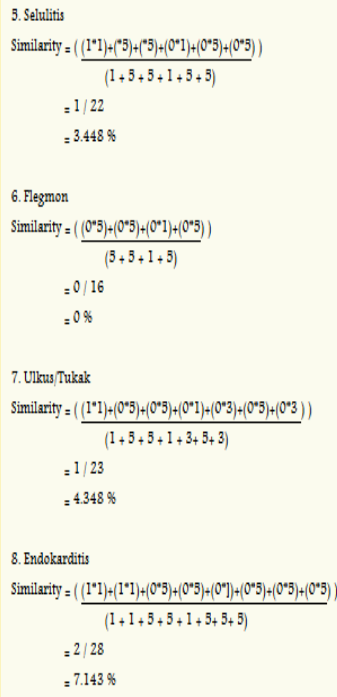

(b)

Gambar 4 (a) dan (b). Halaman Hasil Konsultasi

Berdasarkan dari hasil sistem pakar maka didapatkan sebuah sistem yang sangat membantu pengguna untuk mengetahui penyakit yang dialami secara dini. Hasil dari system ini sangat membantu pasien dari kurangnya tidaktahuan dari penyakit disebabkan oleh bakteri staphylococcus aureus.

\section{Kesimpulan}

Dengan adanya penerapan aplikasi ini dapat membantu untuk mempermudah masyarakat umum untuk mengetahui jenis-jenis penyakit bakteri staphylococcus aureus pada pasien dengan cepat tanpa harus langsung bertemu dokter, serta dapat memberikan penanganan sementara yang terkait dengan penyakit disebabkan oleh bakteri stapgtlococcus aureus.

\section{Daftar Rujukan}

[1] Seran, L., Herak, R., \& Missa, H. (2020). Pembuktian Kemampuan Anti Bakteri Ekstrak Daun dan Kulit Jarak Pagar ( Jatropha culcas ) Terhadap Bakteri Staphylococcus aureus Secara In Vitro dalam Pembelajaran dengan Metode PBL Terhadap Mahasiswa Semester VII Program Studi Pendidikan Biologi FKIP UNWIRA. Jurnal Studi Guru dan Pembelajaran, 3(1), 3950 .

[2] Saifuddin, M. (2019). Implementasi Case Based Reasoning Pada Sistem Pakar Untuk Mendiagnosa Penyakit Tanaman Belimbing. Sains dan Komputer (SAINTIKOM), 18(2).

[3] Ramadhan, P. S., \& Tugiono, T. (2019). Sistem E-Pediatric Untuk Pendiagnosaan Eflorsen Dermatis Menggunakan Teorema Bayes. Jurnal Sebatik, 23(1), 242-247. https://doi.org/10.46984/sebatik.v23i1.476 .

[4] Setiawan, A., \& Wibisono, S. (2018). Case Based Reasoning Untuk Mendiagnosa Penyakit dan Hama Pada Tanaman Mangga Menggunakan Algoritma Similaritas Sorgenfrei. Dinamik, 23(1), 1-10. DOI: https://doi.org/10.35315/dinamik.v23i1.7172 .

[5] Fatoni, C. S., \& Noviandha, F. D. (2017). Case Based Reasoning Diagnosis Penyakit Difteri dengan Algoritma K-Nearest 
Neighbor. Creative Information Technology Journal (CITEC JOURNAL),

4(3),

220

https://doi.org/10.24076/citec.2017v4i3.112.

[6] Hardianto, R. (2018). Sistem Pakar Penentuan Tipe Kepribadian Siswa Sekolah Dasar Menggunakan Metode Case Based Reasoning. INTERCOMS: Journal of Information Technology and Computer Science, 1(2), 240-250. DOI: https://doi.org/10.31539/intecoms.v1i2.298 .

[7] Mulyana, S., \& Sahputra, I. (2018). The Determination of the Action towards the Patient's Psychological Therapy in the Post- accident Using Case-based Reasoning. IJCCS (Indonesian Journal of Computing and Cybernetics Systems), 12(1). DOI: https://doi.org/10.22146/ijccs.22886.

[8] Natassya, A., Tursina, T., \& Sukamto, A. S. (2019). Case Based Reasoning Diagnosis Risiko Penyakit Stroke Menggunakan Metode Hamming Distance. Jurnal Sistem dan Teknologi Informasi (JUSTIN), 7(2), 122. DOI: https://doi.org/10.26418/justin.v7i2.29891 